\title{
STOCK MARKET INTEGRATION BETWEEN TURKEY AND BRICS COUNTRIES: EMPIRICAL EVIDENCE FROM COINTEGRATION TEST WITH STRUCTURAL BREAKS
}

\author{
DOI: 10.17261/Pressacademia.2020.1228 \\ JBEF- V.9-ISS.2-2020(11)-p.189-195
}

\section{Yuksel Iltas}

Kirsehir Ahi Evran University, Faculty of Economics and Administrative Sciences, Department of Business Administration, Kirsehir, Turkey yiltas@ahievran.edu.tr , ORCID:0000-0001-8853-838X

\section{To cite this document}

Iltas. Y., (2020). Stock market integration between Turkey and BRICS countries: empirical evidence from a cointegration test with structural breaks. Journal of Business, Economics and Finance (JBEF), V.9(2), p.189-195.

Permanent link to this document: http://doi.org/10.17261/Pressacademia.2020.1228

Copyright: Published by PressAcademia and limited licensed re-use rights only.

\begin{abstract}
Purpose - The goal of this paper is to examine the cointegration relationship between BIST-100 index and BRICS countries' (Brazil, Russia, India, China, and South Africa) stock market indices using monthly data over the period 2003:01-2019:08. To that end, this paper performs a cointegration test that considers both sharp and gradual breaks.

Methodology - Long term relationship between BIST-100 index and BRICS countries stock indexes for January 2003-August 2019 period is examined by Dickey and Fuller (1981) and Phillips and Perron (1988) unit root test and Tsong et al. (2016) cointegration test with structural breaks. Findings- The empirical findings indicate that BIST-100 index is cointegrated with the stock market indices in Brazil, Russia, and China, while it is not cointegrated with the stock market indices in India and South Africa.

Conclusion- The findings reveal that BIST 100 is not cointegrated with the stock market indices in India and South Africa. These findings imply that investors in BIST can also invest in India's and South Africa's stock markets. In this way, investors will be able to reduce their risks by investing in stock exchange indices which has not long-term relationship (cointegration).
\end{abstract}

Keywords: Stock markets, BIST 100 index, BRICS countries, cointegration test, structural breaks.

JEL Codes: C22, F36, G15

\section{INTRODUCTION}

As denoted by Kearney and Lucey (2004), due to the rapid expansion of international trade, services and financial assets, the degree of interaction between financial markets is increasing day by day. While the interaction between these markets concerns policy makers in terms of the sustainability of financial stability in the country, it also concerns international investors making portfolio diversification for reducing risks in their investment portfolios. The long-term/cointegration relationship between the capital markets of the countries indicates that there is a co-movement among these markets and that the expected return from portfolio diversification among these stock markets will decrease due to their long-term relationship. In this context, investors who include international investments in their portfolios should concentrate on stock market indices with low correlations in order to diversify the risk taken and to increase the return. Otherwise, portfolio diversification consisting of markets with longterm relationship will not provide an opportunity for investors to reduce risk and will not generate required returns for investors.

Identifying the existing relationships between commercially and financially integrated markets is important for both policy makers and fund managers with international portfolio investments. Low correlation and no co-movement between different national stock market indices are often preferred to ensure the international diversification of portfolios (Lim, 2007; Diamandis, 2009). Every potential return to investors investing in stocks in different markets is negatively related to the cointegration levels of stock market indices. Investors will be able to reduce risks through international diversification by benefiting from low correlation or no long-term co-movement between national stock market indices (Shamsuddin and Kim, 2003). 
In the last decades following the stock market crisis in October 1987, capital flows have been faster among economies and stocks have been traded much more easily all around the world as a result of (i) increasing policy coordination, (ii) the removal of obstacles to capital movements in financial markets, (iii) the ending of the intervention of governments on financial markets, (iv) the rapid developments in the trade and communication technologies, and $(v)$ the development of new financial products (Diamandis, 2009). Besides, the increase in the number of financial instruments helped financial liberalization be faster by providing foreign investors with the opportunity to diversify risks.

Especially in the period following 1970s, countries had the opportunity to develop their commercial activities with each other as a result of globalization and financial liberalization. Increasing trade between countries resulted in rising interactions and interdependence among national economies. The current or potential relations of countries with each other concern investors in terms of risk distribution and portfolio diversification and policy makers in terms of trade and development. Therefore, determining the interactions of the markets among each other is both theoretically and practically important.

On May 22, 2013, the Federal Reserve (FED) announced that the magnitude of its third monetary expansion program which had been implemented since September 2012 and would be reduced and the program would be ended in 2014 as well. Following this date, significant fluctuations were observed in both money and capital markets of many developing countries. In this process, some emerging economies performed quite similarly due to some structural vulnerabilities, such as high current account deficits, high inflation rates, and low growth rates (Akel, 2015). Besides, after May 22, 2013, while the interest rates in BRICST countries (Brazil, Russia, India, China, South Africa, and Turkey) increased, there was a serious decrease in the stock market indices of these countries. Figure 1 exhibits 10-year government bond interest rates in BRICST countries during the year 2013 with a dashed line for May 2013. As is seen in the figure, 10-year government bond yields of Turkey and Brazil grew faster compared to those of other countries. The increase in bond interest rates of India, China, South Africa, and Russia was relatively low.

Figure 1: 10-year Bond Interest of BRICST Countries

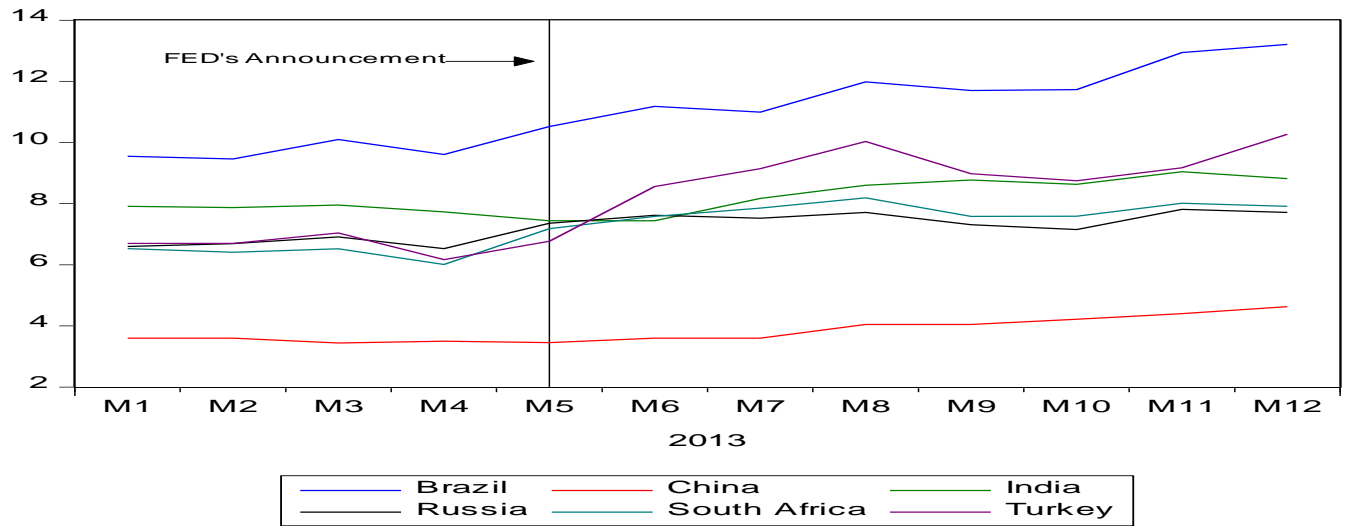

Source: Investing.com (2019)

These developments may indicate a rise in the level of integration of domestic capital markets. Besides, some studies analyzing whether or not there exists a long-term relationship between national stock market indices has increased in the last years. Within this scope, this paper investigates whether there exists a co-movement between BIST-100 index and the stock market indices in BRICS countries over the period 2003-2019 by employing a recently developed cointegration test that presents efficient results in the existence of both sharp and gradual breaks. Hence, the main contribution of this paper to the extant literature is that it is the first paper that considers both gradual and sharp breaks while examining the cointegration relationship between stock markets.

The rest of the paper is as follows: Section 2 presents the empirical literature. Section 3 introduces data. Estimation methodology and findings are given in Section 4 . Section 5 concludes the paper.

\section{LITERATURE REVIEW}

Financial market theories suggest that portfolios invested in fully integrated markets carry both global and local risks. While local risks are eliminated in the portfolio by investing in international stock markets (portfolio diversification), only global risks are priced (Lehkonen, 2015). The vast majority of markets, especially the emerging ones, are partially integrated. In these markets, 
stock prices reflect both local and global factors and expected returns are determined by these two sources of risks (Bekaert and Harvey, 1995). Although local risks are important determinants of returns in emerging markets, the importance of them has weakened for most markets due to the further integration of financial markets (Bekaert and Harvey, 1995; Carrieri et al. 2007; Pukthuanthong and Roll, 2009; Bekaert et al. 2011; Arouri, Nguyen, and Pukthuanthong, 2012).

There exists a vast literature the literature examining the cointegration relationship between stock markets. This paper classifies the empirical literature into two groups. The first group of the papers investigated the relation among the stock market indices of different countries rather than Turkey. For instance, Kanas (1998) examined the cointegration relationship between the stock market indices of the USA and six European countries (UK, Germany, France, Switzerland, Italy and Netherlands). According to the findings of the study, no long-term relationship between the USA's stock market index and six European countries' stock market indices was found. Similarly, Tabak and Lima (2002) investigated the relationship between the US stock market index and the stock market indices of seven Latin American countries (Argentina, Brazil, Chile, Colombia, Mexico, Peru, and Venezuela). According to the results, a long-term relationship between the USA's and other countries' stock market indices was not established. Chang and Lu (2006) investigated the long-term relationship between the stock market indices of Shanghai and Shenzhen using different cointegration tests. The results of all cointegration tests indicated there existed no relationship between these indices. Aktan et al. (2009) examined the relationships among the stock market indices of BRICA countries (Brazil, Russia, India, China, and Argentina) and stock market index of the USA. In the short term, they found that the US stock market had a significant impact on the stock markets of all BRICA countries. While the cointegration relationship between the stock market indices of Russia and Brazil was strong, the cointegration relationship between the stock markets of China and Argentina was weak. According to the Granger causality results, the Russian stock market affected the stock markets of all other countries. In addition, while the stock market of Brazil affected the stock markets of Argentina, Russia, and India, the stock market of China affected only the stock markets of Argentina and Russia. Chang and Tzeng (2009) examined the nexus between the stock market of the USA and those of the four major trading partners of the US (Canada, Germany, Japan, and the Mexico). According to the empirical findings, the US stock market was only cointegrated with the Mexican stock market. Chittedi (2010) investigated the long-term relationship and the causal nexus between the stock market indices of BRIC countries and those of developed countries, such as the USA, the UK, and Japan. According to the findings of the study, there was a long-term relationship between the stock market indices of BRIC countries and those of developed countries. Besides, it was determined that the stock markets of the USA and Japan influenced the Indian stock market, while the stock markets of Brazil and Russia were affected by the Indian stock market.

The second group of the studies investigated the nexus between BIST 100 and some countries' stock market indices. For instance, Bayrı and Güloğlu (2005) examined the relation between BIST 100 and the stock market indices of European Union (EU) and the US. They discovered BIST 100 was related to the stock market indices of EU and the USA. Mandacı and Taşkın (2005) examined the relation between BIST 100 and 17 European stock market indices (Germany, Austria, Denmark, Belgium, France, the Netherlands, Portugal, Finland, the UK, Ireland, Spain, Sweden, Italy, Hungary, Norway, Poland, and Greece). In the study, it was observed that the relationship between the European stock market indices and BIST 100 was quite weak, and it was concluded that the stock market of Turkey could be an alternative investment tool to European stock markets. Marashdeh (2005) inspected the cointegration relation between the stock market indices of Turkey, Egypt, Jordan, and Morocco and those of some developed countries (the US, Germany, and the UK). The results indicated that there existed a co-movement between the stock market indices of Turkey, Egypt, Jordan, and Morocco, but there was no long-term relation between the stock market indices of these countries and those of developed countries. Çıtak and Gözbaşı (2007) investigated the long-term relation between BIST 100 and the stock market indices of the USA, Germany, India, the UK, Japan, and Malaysia. In the study, a long-term relation was found between BIST 100 and the stock market indices of the USA, Germany, India, and the UK. Korkmaz, Zaman, and Çevik (2007) examined whether there occured a cointegration relationship between BIST 100 and the stock market indices of many developed and developing countries by using a cointegration test with structural breaks. According to the findings, BIST 100 was cointegrated with the stock market indices of 16 developed and 21 developing countries. Sevüktekin and Nargeleçekenler (2008) examined the interaction between the US stock market indices (Dow Jones, Nasdaq, and S\&P 500) and BIST 100. A long-term relationship was determined between the relevant stock markets. Additionally, while there was bidirectional causality in the long run, there existed unidirectional causality running from the US stock market indices to BIST 100 in the short run. Bozoklu and Saydam (2010) investigated the cointegration relationship between BIST 100 and the stock market indices of the BRIC countries (Brazil, Russia, India and China). According to the cointegration test's results, they found out that BIST-100 index was cointegrated with BRIC countries' stock market indices. Gözbaşı (2010) investigated the relationship between BIST 100 and the stock market indices of Argentina, Brazil, Mexico, India, Malaysia, Hungary, and Egypt. The findings indicated that while BIST 100 was associated with the 
stock market indices of Brazil, India, and Egypt in the long term, it was related to the stock market indices of Brazil, India, Egypt, Mexico, and Hungary in the short term. Vuran (2010) tested the long-term relationship between BIST 100 and the stock market indices of the USA, the UK, France, Germany, Japan, Brazil, Argentina, and Mexico through a cointegration test. The study found that BIST 100 was related to stock market indices of Germany, Argentina, Brazil, the UK and Mexico in the long term. Boztosun and Çelik (2011) investigated the long-term relation between BIST 100 and some European stock market indices (Germany, Austria, Belgium, France, the Netherlands, the UK, Spain, Sweden, Switzerland, and Norway). According to the results, BIST 100 was cointegrated with the stock market indices of Germany, Belgium, the Netherlands, the UK, and Norway. Akel (2015) tested the cointegration and causal relationship between the stock market indices of the fragile five countries, namely Brazil, Indonesia, South Africa, India, and Turkey. He explored that there was no cointegration and causal relationship between the stock market indices of these countries. Finally, Özşahin (2017) tested the relation between BIST 100 and the stock market indices of the BRICS (Brazil, Russia, India, China and South Africa) countries. According to the empirical findings, BIST-100 index was cointegrated with all the stock market indices except for the stock market index in Brazil.

It can be observed from the empirical literature that the previous papers did not exhibit clear-cut evidence about the relationships between the stock market indices of countries. It may be argued that different empirical findings stem from different countries, time periods, and estimation methodologies.

\section{DATA AND METHODOLOGY}

This paper investigates whether BIST 100 is related to the stock market indices of the BRICS countries (Brazil, Russia, India, China, and South Africa) using monthly data over the period 2003:01-2019:08. Data are extracted from Morgan Stanley Capital International (2019). All series are priced in USD. Table 1 depicts the series used in the empirical analysis.

Table 1: Definitions of the Series

\begin{tabular}{|l|l|l|l|}
\hline Country & Stock Market & Stock Market Index & Symbol \\
\hline Turkey & Borsa İstanbul (BIST) & BIST 100 & BIST 100 \\
\hline Brazil & Bolsa de Valores de Sao Paulo & IBOVESPA & BVSP \\
\hline Russia & Moscow Times Index & RTSI Index & RTSI \\
\hline India & Bombay Stock Exchange & BSE Sensex & BSE \\
\hline China & Shanghai Stock Exchange & SSEC & SSE \\
\hline South Africa & Johannesburg Stock Exchange & JSE & JSE \\
\hline
\end{tabular}

In time series analyses, the first step is to examine the stationarity properties of the series through some unit root tests. This paper performs the Augmented Dickey and Fuller (1981, hereafter ADF) and the Phillips and Perron (1988, hereafter PP) unit root tests to determine the order of integration of the variables. Both methods test for the null hypothesis of non-stationarity.

If variables under consideration are found to be stationary at first difference, the long-run relationship between them can be examined through a cointegration test. This paper performs the recently suggested cointegration test of Tsong et al. (2016) that considers both sharp and gradual breaks to test for cointegration.

To consider both sharp and gradual breaks, Tsong et al. (2016) suggest a cointegration test with the Fourier approximation. Besides paying attention to both sharp and gradual breaks, this test is able to report efficient findings irrespective of the number of the breaks. They start using the following model:

$$
y_{t}=d_{t}+x_{t}^{\prime} \beta+\eta_{t^{\prime}} \quad \eta_{t}=v_{t}+u_{1 t}, \quad v_{t}=v_{t-1}+u_{t}, \quad x_{t}=x_{t-1}+u_{2 t}
$$

In Equation (1), $u_{t}$ denotes the error term and $\nu_{t}$ demonstrates a random walk. In this equation, $d_{t}$ is described as $d_{t}=\delta_{0}+f_{t}$. In this model, $f_{\mathrm{t}}$ implies the Fourier function defined as follows:

$f_{\mathrm{t}}=\alpha_{\mathrm{k}} \sin \left(\frac{2 \mathrm{k} \pi \mathrm{t}}{\mathrm{T}}\right)+\alpha_{\mathrm{k}} \cos \left(\frac{2 \mathrm{k} \pi \mathrm{t}}{\mathrm{T}}\right)$ 
where $T$ is the number of observations, $t$ stands for time trend, and $k$ denotes the Fourier frequency. If $\sigma_{u}^{2}=0, \eta_{t}=u_{1 t}$ is stationary. This condition indicates there occurs cointegration in the empirical model. Thus, the null hypothesis of cointegration against the alternative hypothesis of no cointegration is depicted as below:

$H_{0}: \sigma_{u}^{2}=0$ versus $H_{1}: \sigma_{u}^{2}>0$

In order to test the null hypothesis, the model in Equation (1) can be redescribed as below:

$y_{t}=\sum_{i=0}^{m} \delta_{i} t^{i}+\alpha_{k} \sin \left(\frac{2 k \pi t}{T}\right)+\beta_{k} \cos \left(\frac{2 k \pi t}{T}\right)+x_{t}^{\prime} \beta+u_{1 t}$

The test statistic for cointegration can be defined as $\mathrm{Cl}_{\mathrm{f}}^{\mathrm{m}}=\mathrm{T}^{-2} \widehat{\omega}_{1}^{-2} \sum_{\mathrm{t}=1}^{\mathrm{T}} \mathrm{S}_{\mathrm{t}}^{2}$, where $\mathrm{St}$ is the partial sum of the ordinary least squares (OLS) residuals in Equation (4) and $\widehat{\omega}_{1}^{2}$ implies the consistent estimator of the long-run variance of $U_{11}$.

Tsong et al. (2016) also test if the model should contain the Fourier component. Put differently, they examine whether or not the cointegration testing procedure should be based on the Fourier approach through F test. Tsong et al. (2016) estimates Equation (4) via the dynamic OLS estimator of Saikkonen (1991).

\section{EMPIRICAL RESULTS}

Table 2 reports the results for the ADF and PP unit root tests. Accordingly, the null hypothesis of non-stationarity can be rejected at first differences for all of the series. In other words, all variables seem to be integrated of order one. Hence, the findings of the unit root tests imply that the cointegration relation between BIST 100 and the stock market indices of BRICS countries can be examined.

\section{Table 2: Results of ADF and PP Unit Root Tests}

\begin{tabular}{|l|l|c|c|c|c|}
\hline \multirow{2}{*}{ Variable } & \multicolumn{2}{|c|}{ ADF } & \multicolumn{2}{c|}{ PP } \\
\cline { 3 - 6 } & Level & Intercept & Intercept and trend & Intercept & Intercept and trend \\
\hline \multirow{2}{*}{ BIST 100 } & -2.594 & -2.461 & -2.697 & -2.520 \\
\cline { 2 - 6 } & $\mathbf{1}^{\text {st }}$ dif. & $-13.926^{*}$ & $-14.015^{*}$ & $-13.925^{*}$ & $-14.022^{*}$ \\
\hline \multirow{2}{*}{ BVSP } & Level & -2.180 & -2.028 & -2.367 & -2.234 \\
\cline { 2 - 6 } & $\mathbf{1}^{\text {st }}$ dif. & $-12.358^{*}$ & $-12.395^{*}$ & $-12.428^{*}$ & $-12.415^{*}$ \\
\hline \multirow{2}{*}{ RTSI } & Level & -2.502 & -2.701 & -2.562 & -2.729 \\
\cline { 2 - 6 } & $\mathbf{1}^{\text {st }}$ dif. & $-11.525^{*}$ & $-11.531^{*}$ & $-11.607^{*}$ & $-11.612^{*}$ \\
\hline \multirow{2}{*}{ BSE } & Level & -2.164 & -2.646 & -2.228 & -2.917 \\
\cline { 2 - 6 } & $\mathbf{1}^{\text {st dif. }}$ & $-13.667^{*}$ & $-13.663^{*}$ & $-13.687^{*}$ & $-13.681^{*}$ \\
\hline \multirow{2}{*}{ SSE } & Level & -2.120 & -2.648 & -2.151 & -2.924 \\
\cline { 2 - 6 } & $\mathbf{1}^{\text {st }}$ dif. & $-13.258^{*}$ & $-13.250^{*}$ & $-13.255^{*}$ & $-13.247^{*}$ \\
\hline \multirow{2}{*}{ JSE } & Level & -2.701 & -2.586 & -2.666 & -2.475 \\
\cline { 2 - 6 } & $\mathbf{1}^{\text {st dif. }}$ & $-15.273^{*}$ & $-15.354^{*}$ & $-15.275^{*}$ & $-15.354^{*}$ \\
\hline
\end{tabular}

Notes: $5 \%$ critical values are respectively -2.875 and -3.432 for the models with intercept and with intercept and trend. ${ }^{*}$ indicates statistical significance.

Table 3 presents the empirical results for the cointegration test. Accordingly, the null hypothesis that the Fourier component should not be included in the empirical model is rejected for all models in the paper. Put differently, the empirical findings indicate the Tsong et al. (2016) test to cointegration should be performed to investigate the cointegration relation between BIST 100 and BRICS's countries stock market indices. Besides, the null hypothesis of cointegration is rejected for the relationship between BIST 100 and BSE and between BIST 100 and JSE, while it is not rejected for other models. Hence, the empirical findings imply that BIST 100 is cointegrated with BVSP, RTSI, and SSE, whereas it is not cointegrated with BSE and JSE. In other words, the paper explores that the stock market index in Turkey is cointegrated with the stock market indices in Brazil, Russia, and China and is not cointegrated with the stock market indices in India and South Africa.

Table 3: Results for Cointegration Test 


\begin{tabular}{|l|c|c|}
\hline Cointegration Relationship & Frequency (k) & Test statistic \\
\hline BIST 100-BVSP & 2 & 0.218 \\
\hline BIST 100-RTSI & 1 & 0.052 \\
\hline BIST 100-BSE & 1 & $11.493^{*}$ \\
\hline BIST 100-SSE & 1 & $0.146^{*}$ \\
\hline BIST 100-JSE & 1 & 0.106 \\
\hline
\end{tabular}

Notes: For test statistic, $5 \%$ critical values for $\mathrm{k}=1$ and $\mathrm{k}=2$ are respectively 0.124 and 0.276 . For $\mathrm{F}$ statistic, $5 \%$ critical value is 4.066 . $*$ illustrates statistical significance.

Hence, the empirical findings of this paper majorly are similar with those of Bozoklu and Saydam (2010) and Akel (2015) and substantially contradict with those of Özşahin (2017). On one hand, the output of the paper for the cointegration relationship between BIST 100 and BVSP is compatible with those of Gözbaşı (2010) and Vuran (2010). On the other hand, the results of the empirical analysis of the present paper about the cointegration relationship between BIST 100 and BSE conflicts with those of Gözbaşı (2010).

\section{CONCLUSION}

This paper has empirically investigated the cointegration relation between BIST 100 and the stock market indices in BRICS countries using monthly data from 2003:01 to 2019:8. After determining all the series were integrated of order one, the paper employed the Tsong et al. (2016) cointegration test with structural breaks. The cointegration test's results indicate that BIST 100 is cointegrated with the stock market indices in Brazil, Russia, and China and is not cointegrated with the stock market indices in India and South Africa. These empirical findings provide researchers and international investors some considerable inferences.

The findings of the paper indicate that the BIST 100 index has a long-term relationship that moves together with Brazil's, Russia's, and Chine's stock market indices. These findings imply that it is not possible to gain returns by making international portfolio diversification and arbitrage between BIST and these stock markets. The findings also posit that investors in BIST can also invest in India's and South Africa's stock markets as these stock markets do not have a long-term relationship with BIST. In other words, the stocks in India and South Africa can be an alternative investment tool for the stocks in Turkey. Hence, it can be argued that investors who have the stocks in BIST in their portfolios can also invest in the stocks in India's and South Africa's stock markets and can have the opportunity to increase their returns from stocks.

\section{REFERENCES}

Akel, V. (2015). Kırılgan Beşli Ülkelerinin Hisse Senedi Piyasaları Arasındaki Eşbütünleşme Analizi. Uluslararası Yönetim Iktisat ve Işsletme Dergisi, 11(24), 75-96.

Aktan, B., Mandacl, P. E., Kopurlu, B. S., and Ersener, B. (2009). Behaviour of Emerging Stock Markets In The Global Financial Meltdown: Evidence From BRIC-A. African Journal of Business Management, 3(9), 396-404.

Arouri, M. E. H., Nguyen, D. K., and Pukthuanthong, K. (2012). An International CAPM For Partially Integrated Markets: Theory and Empirical Evidence. Journal of Banking and Finance, 36(9), 2473-2493.

Bayri, O., and Güloğlu, B. (2005). Hisse Senedi ve Yabancı Para Piyasalarının Entegrasyonu: Türkiye, AB, ABD Örneği. iktisat, işletme ve Finans, 20(234), 13-34.

Bekaert, G., and Harvey, C. R. (1995). Time-Varying World Market Integration. The Journal of Finance, 50(2), 403-444.

Bekaert, G., Harvey, C. R., Lundblad, C. T., and Siegel, S. (2011). What Segments Equity Markets? Review of Financial Studies, 24(12), 3841-3890.

Bozoklu, Ş., and Saydam, İ. M. (2010). BRIC Ülkeleri ve Türkiye Arasındaki Sermaye Piyasaları Entegrasyonunun Parametrik ve Parametrik Olmayan Eşbütünleşme Testleri ile Analizi. Maliye Dergisi, 159, 416-431.

Boztosun, D., and Çelik, T. (2011). Türkiye Borsasının Avrupa Borsaları ile Eşbütünleşme Analizi. Süleyman Demirel Üniversitesi iktisadi ve idari Bilimler Fakültesi Dergisi, 16(1), 147-162.

Carrieri, F., Errunza, V., Hogan, K., Carrieri, F., Errunza, V., and Hogan, K. (2007). Characterizing World Market Integration through Time. The Journal of Financial and Quantitative Analysis, 42(4), 915-940.

Chang, T., and Lu, Y. C. (2006). Equity Diversification in Two Chinese Share Markets: Old Wine and New Bottle. Economics Bulletin, 7(4), 1-7. 
Chang, T., and Tzeng, H. W. (2009). International Equity Diversification Between The United States and Its Major Trading Partners: Nonparametric Cointegration Test. International Research Journal of Finance and Economics, 32, 139-147.

Chittedi, K. R. (2010). Global Stock Markets Development and Integration: With Special Reference to BRIC Countries. International Review of Applied Financial Issues and Economics, (1), 018-036.

Çıtak, L., and Gözbaşı, O. (2007). IMKB ile Önde Gelen Gelişmiş ve Gelişmekte Olan Ülke Borsaları Arasındaki Bütünleşmenin Temel Endeks ve Ana Sektör Endeksleri Temelinde Analizi. Dokuz Eylül Üniversitesi Iktisadi ve Idari Bilimler Fakültesi Dergisi, 22(2), 249-271.

Diamandis, P. F. (2009). International Stock Market Linkages: Evidence From Latin America. Global Finance Journal, 20(1), 13-30. https://doi.org/10.1016/j.gfj.2009.03.005

Dickey, D. A., and Fuller, W. A. (1981). Likelihood Ratio Statistics for Autoregressive Time Series with a Unit Root. Econometrica, $49(4), 1057$.

Gözbaşı, O. (2010). IMKB ile Gelişmekte Olan Ülkelerin Hisse Senedi Piyasalarının Etkileşimi: Eşbütünleşme ve Nedensellik Yaklaşımı. Erciyes Üniversitesi iktisadi ve Idari Bilimler Fakültesi Dergisi, 35, 99-118.

Kanas, A. (1998). Linkages Between The US and European Equity Markets: Further Evidence From Cointegration Tests. Applied Financial Economics, $8(6), 607-614$.

Kearney, C., and Lucey, B. M. (2004). International equity market integration: Theory, evidence and implications. International Review of Financial Analysis, 13(5 SPEC.ISS.).

Korkmaz, T., Zaman, S., and Çevik, E. İ. (2007). IMKB ile Uluslararası Hisse Senedi Piyasaları Arasındaki Entegrasyon Illişkisinin Yapısal Kırılma Testleri ile Analizi. Akdeniz i.i.B.F. Dergisi, 17, 40-71.

Lehkonen, H. (2015). Stock Market Integration and the Global Financial Crisis. Review of Finance, 19(5), 2039-2094.

Lim, L. K. (2007). Linkages between ASEAN stock markets: A cointegration approach. MMODSIM 2007 International Congress on Modelling and Simulation, 1818-1824.

Mandacı, P. E., and Taşkın, D. (2005). AB'ye Uyum Sürecinde iMKB'nin AB Piyasaları ile Karşılaştırılması. Muhasebe ve Finansman Dergisi, 26, 127137.

Marashdeh, H. (2005). Stock Market Integration in the MENA Region: An Application of the ARDL Bounds Testing Approach. Faculty of CommerceEconomics Working Papers, 05-27(November), 1-14.

Özşahin, Ş. (2017). Yükselen Piyasa Ekonomilerinde Menkul Kıymetler Borsalarının Entegrasyonu: Türkiye ve BRıCS Ülkeleri Üzerine Çoklu Yapısal Kırılmalı Eş-bütünleşme Analizi. Yönetim ve Ekonomi: Celal Bayar Üniversitesi Iktisadi ve İdari Bilimler Fakültesi Dergisi, 24(2), 601-619.

Phillips, P. C. B., and Perron, P. (1988). Testing for a unit root in time series regression. Biometrika, 75(2), 335-346.

Pukthuanthong, K., and Roll, R. (2009). Global market integration: An alternative measure and its application. Journal of Financial Economics, 94(2), 214-232.

Sevüktekin, M., and Nargeleçekenler, M. (2008). Türkiye ve Amerika'daki Hisse Senedi Piyasaları Arasındaki Dinamik İlişkinin Belirlenmesi. Finans Politik \& Ekonomik Yorumlar, 45(520), 15-22.

Shamsuddin, A. F. M., and Kim, J. H. (2003). Integration and interdependence of stock and foreign exchange markets: An Australian perspective. Journal of International Financial Markets, Institutions and Money, 13(3), 237-254.

Tabak, B. M., \& Lima, E. J. A. (2002). Causality and Cointegration in Stock Markets: the Case of Latin America. Banco Central Do Brasil Working Paper Series, 56, 3-24.

Tsong, C. C., Lee, C. F., Tsai, L. J., and Hu, T. C. (2016). The Fourier Approximation and Testing For The Null of Cointegration. Empirical Economics, 51(3), 1085-1113.

Vuran, B. (2010). IMKB 100 Endeksinin Uluslararası Hisse Senedi Endeksleri ile İlişkisinin Eşbütünleşim Analizi ile Belirlenmesi. İstanbul Üniversitesi İsletme Fakültesi Dergisi, 39(1), 154-168. 